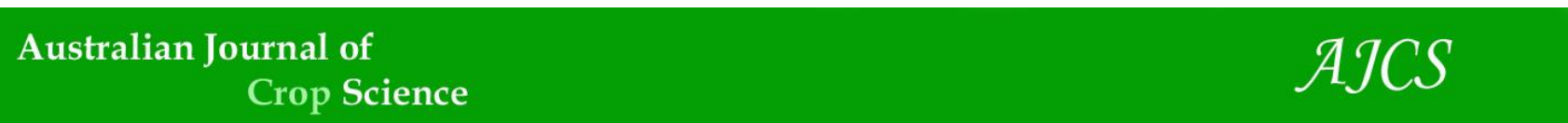

AJCS 15(02):305-311 (2021)

ISSN:1835-2707

doi: 10.21475/ajcs.21.15.02.p2999

\title{
Herbicides in agronomic performance and chlorophyll indices of Enlist E3 and Roundup Ready soybean
}

\author{
André Felipe Moreira Silva ${ }^{1 *}$, Felipe Ridolfo Lucio ${ }^{2}$, Lucas Rafael de Marco ${ }^{1}$, Ana Ligia Giraldeli ${ }^{1}$, Alfredo \\ Junior Paiola Albrecht ${ }^{3}$, Leandro Paiola Albrecht ${ }^{3}$, Ricardo Victoria Filho ${ }^{1}$, Felipe Alves Nunes ${ }^{2}$ \\ 'University of São Paulo, “Luiz de Queiroz” College of Agriculture, Piracicaba, São Paulo, Brazil
${ }^{2}$ Corteva Agriscience, Mogi-Mirim, São Paulo, Brazil
${ }^{3}$ Federal University of Paraná, Palotina, Paraná, Brazil
}

*Corresponding author: afmoreirasilva@hotmail.com

\begin{abstract}
Soybean DAS-44406-6 (Enlist E3) is tolerant to glyphosate, 2,4-D and glufosinate. However, more information is needed on selectivity of 2,4-D choline on Enlist E3 soybean, alone or in mixtures. The aim of this study was to evaluate herbicide effects on agronomic performance and chlorophyll indices of soybean. Glyphosate was applied at different stages of development of Enlist E3 and RR soybean. Furthermore, 2,4-D choline alone and in mixture with glyphosate or glufosinate were also applied on Enlist E3 soybean. Studies were conducted in 2016/17 and 2017/18 seasons. Experiment 1 consisted of application of glyphosate. The treatments were arranged in a $2 \times 4$ factorial (genotpes $x$ growth stage). For genotypes, Enlist E3 and RR were used. For growth stage, control (without application), V4, V6 and R2 were used. Experiment 2 consisted of application of 2,4-D choline, glyphosate, glufosinate and associations, at V4 of Enlist E3 soybean. Crop injury, chlorophyll indices and agronomic performance were evaluated. The equivalent selectivity of glyphosate for Enlist E3 and RR soybean was verified, regardless of the stage. 2,4-D choline, alone or in mixtures, did not reduce chlorophyll indices and yield of Enlist E3 soybean after application at V4. Enlist E3 soybean was found to be tolerant to 2,4-D choline, glyphosate and glufosinate. The results showed that, in addition to glyphosate, Enlist E3 soybean may be an alternative for glyphosate resistant weeds.
\end{abstract}

Keywords: 2,4-D; auxinic synthetics; Glycine max L.; glyphosate; glufosinate; herbicide-tolerant crops; selectivity.

Abbreviations: 2mepsps_enzyme double mutant 5-enolpyruvylshikimate-3-phosphate synthase; aad-12_aryloxyalkanoate dioxygenase-12; Cl_chlorophyll index; E3_Enlist E3 soybean; epsps_enzyme double mutant 5-enolpyruvylshikimate-3-phosphate synthase; FI_Falker chlorophyll; pat_phosphinothricin acetyltransferase; RR_Roundup Ready soybean; SPAD_Soil Plant Analysis Development; WAA_weeks after the application.

\section{Introduction}

The transgenic event GTS 40-3-2 (Roundup Ready ${ }^{\mathrm{TM}}$ - RR, Monsanto Company) confers tolerance to herbicide glyphosate to soybean. It has been developed by introducing the gene encoding a glyphosate-insensitive 5-enolpyruvylshikimate-3-phosphate synthase (EPSPs) enzyme, denominate cp4epsps, derived from the Agrobacterium tumefaciens (Padgette et al., 1995).

The transgenic event DAS-44406-6 (Enlist E3 ${ }^{\text {TM }}$, Dow AgroSciences) confers tolerance to herbicides glyphosate, 2,4-D and glufosinate to soybean, respectively conferred by enzymes double mutant 5-enolpyruvylshikimate-3phosphate synthase (2MEPSPS), aryloxyalkanoate dioxygenase-12 (AAD-12) and phosphinothricin acetyltransferase (PAT). The enzyme 2MEPSPS is encoded by the EPSPs gene that underwent double mutagenesis (2mepsps) from maize. The enzyme AAD-12 is encoded by the aad-12 gene derived from soil bacteria Delftia acidovorans MC1, while the PAT enzyme is encoded by the pat gene from Streptomyces viridochromogenes (Lepping et al., 2013).

Glyphosate is classified as post-emergence, non-selective (selective only for tolerant genetically modified). It inhibits the activity of the EPSPs enzyme, having a broad spectrum of action and systemic action (Oliveira Júnior, 2011). 2,4-D belongs to the group of synthetic auxins. This group has great historical importance, since 2,4-D was the first organic compound synthesized industrially as a selective herbicide. These herbicides have greater control of eudicotyledons weeds (Peterson et al., 2016). Glufosinate is a broadspectrum, non-selective (selective only for crops with the pat gene). It presents contact action and limited translocation (Oliveira Júnior, 2011).

In addition to Enlist E3 soybean, a premix formulation was developed whose composition includes 2,4-D (choline salt) and glyphosate. 2,4-D choline has less drift potential and less volatility in comparison to dimethylamine formulation. The application can be performed up to the R2 stage of Enlist E3 soybean, until rate of 2,185 $\mathrm{g}$ ae ha ${ }^{-1}$ (Chahal et al., 2015). Glyphosate can be applied in RR soybean, up to the R1 stage (Rodrigues and Almeida, 2018). Higher rates of glyphosate $\left(2,880 \mathrm{~g}\right.$ ae ha $\left.{ }^{-1}\right)$ and late applications (V6-R2) may adversely affect photosynthetic parameters and chlorophyll indices of RR soybean. Symptoms are characterized by yellow flashing (yellowing of upper leaves) (Zobiole et al., 2010). In some situations, it can be accompanied by yield reductions 
(Albrecht et al., 2011). In Enlist E3 soybean, there are no reports of reductions in photosynthetic parameters and chlorophyll indices after glyphosate application. Schryver et al. (2017) found that crop injury was at most $2 \%$ after application of glyphosate (881.5 $\mathrm{g}$ ae ha ${ }^{-1}$ ). Also, Enlist E3 soybean was tolerant to 2,4-D alone (Robinson et al., 2015) or in mixtures (Miller and Norsworthy, 2016), with no reports of reductions in photosynthetic parameters and chlorophyll indices.

Based on the different enzymes that confer resistance to glyphosate to Enlist E3 and RR soybean at the maximum recommended stage for application, it is believed that there may be differences between Enlist E3 and RR soybean for tolerance to the herbicide glyphosate, when applied at different phenological stages. More information is necessary on selectivity of 2,4-D choline in Enlist E3 soybean, alone or in mixtures. The aim of this study was to evaluate the herbicide effects on agronomic performance and chlorophyll indices of soybean. We applied Glyphosate at different stages of development in Enlist E3 and RR soybean, and 2,4$D$ choline alone and in mixture with glyphosate (premix formulation or tank mixture) or glufosinate on Enlist E3 soybean.

\section{Results}

\section{Crop injury}

Data analysis did not indicate differences among the treatments, for crop injury at experiment $1(P>0.05)$. Symptoms of injury about $1 \%$ were found because of the application of glyphosate in soybean plants. At experiment 2 , no differences were found between the treatments for crop injury in Enlist E3 soybean plants after application of 2,4-D choline, glyphosate and glufosinate at V4 $(P>0.05)$. Absolute values of a maximum of $3 \%$ were found (data not shown).

\section{Chlorophyll indices}

For experiment 1 , there were some differences between the treatments for chlorophyll index (SPAD) from 1 to 3 WAA for the 2016/17 season. However, the data analysis did not indicate differences between treatments at 4 WAA (Table 2). For chlorophyll indices (FC) A, B and total (2017/18 season), there was no differences between the two factors, nor a significant interaction between the factors $(P>0.05)$ (data not shown). Similarly at experiment 2 , we observed no significant difference on chlorophyll index (SPAD between treatments (2016/17 season) $(P>0.05)$ (data not shown). The same result was found for the 2017/18 season from 1 and 2 WAA for chlorophyll indices (FC) A, B and total. However, there were differences among treatments at 3 and 4 WAA (Table 3). At 3 WAA, differences were found for the total chlorophyll index, while for chlorophyll $A$ index at 4 WAA. The application of 2,4-D choline reduced the values when compared to the application of 2,4-D choline + glufosinate. At the same time any treatment reduced the chlorophyll indices compared to the control.

\section{Agronomic performance}

For variables related to agronomic performance (plant height, number of pods per plant, yield, and 1,000-grain weight), there were no differences between levels of event factors and stage, as well as no significant interaction between the factors for both seasons of the experiment 1 (Table 4). Also at experiment 2, for any of the variables related to agronomic performance of Enlist E3 soybean plants, there were differences between treatments for the $2016 / 17$ season. However, for the $2017 / 18$ season, there were differences between treatments for number of pods per plant. The post-emergence application of 2,4-D choline + glufosinate reduced the number of pods per Enlist E3 soybean plant, compared to the control. But the values found for this treatment did not differ from those found for the other herbicide treatments. The application of the other herbicides did not reduce the number of pods per plant compared to the control. It should be noted that for the other variables, there were no differences among treatments for both seasons, including yield. As for all variables, no differences were observed between the application in premix formulation or tank mixture of 2,4-D choline + glyphosate (Table 5)

\section{Discussion}

RR soybean showed no crop injury after glyphosate application (960 $\mathrm{g}$ ae $\mathrm{ha}^{-1}$ ) at $\mathrm{V} 4$, as well as no reductions in chlorophyll indices, yield, height, and number of pods per plant (Silva et al., 2016). Bohm et al. (2014) also did not find reductions in yield of RR soybean after application of glyphosate (960 ae ha ${ }^{-1}$ ) at 28 and 56 days after sowing. These results corroborate the findings for RR soybean in the present study. However, Albrecht et al. (2018) found crop injury and reductions in chlorophyll indices after application of higher rates $\left(2,880 \mathrm{~g}\right.$ ae ha $\left.{ }^{-1}\right)$ of glyphosate at V4 of RR soybean, without yield reductions. Such injury in glyphosate tolerant soybeans is characterized by yellow flashing, which can be defined as a visual symptom of the negative effect of glyphosate on photosynthetic parameters and chlorophyll content (Zobiole et al., 2010). This symptom may be related to the accumulation of aminomethylphosphonic acid (AMPA), which is a phytotoxic metabolite of glyphosate (Reddy et al., 2004). In addition to yellow flashing, other studies have reported reductions in RR soybean yield, especially for high doses of glyphosate $\left(2,880 \mathrm{~g}_{\text {ae }} \mathrm{ha}^{-1}\right)$ and late applications (R2) (Albrecht et al., 2011). Thus, this symptom may indicate possible reductions in yield in some situations. In Enlist E3 soybean, there are no reports of reductions in photosynthetic parameters and chlorophyll indices after glyphosate application. Schryver et al. (2017) found that crop injury was almost $2 \%$ after application of glyphosate $\left(881.5 \mathrm{~g}\right.$ ae $\left.\mathrm{ha}^{-1}\right)$ at post-emergence. These results are similar to those found in the present study for post-emergence application of glyphosate $\left(1,440 \mathrm{~g}_{\text {ae }} \mathrm{ha}^{-1}\right)$ at different phenological stages of Enlist E3 soybean. Neither significant crop injury, yield and other agronomic performance variables for RR soybean was observed nor differences were found among variables between soybean cultivars. Tolerance to glyphosate in Enlist E3 soybean is conferred by the 2mepsps gene (Lepping et al., 2013), whereas in RR soybean, it is conferred by the cp4epsps gene (Padgette et al., 1995). The 2mepsps gene is also present in glyphosate tolerant cotton (GHB614 - GlyTol ) (Green, 2009). The four-stage sequential application of glyphosate $(1,300 \mathrm{~g}$ ae $\mathrm{ha}^{-1}$ ) in cotton (2mepsps transformed) did not cause crop injury and did not reduce yield of cotton plants (Wallace et al., 2011). 
Table 1. Treatments composed of isolated or associated application of herbicides in soybean plants. Mogi-Mirim, SP, Brazil (experiment 2).

\begin{tabular}{|c|c|c|}
\hline Treatments $^{1}$ & Commercial product & Rates $^{2}$ \\
\hline 1. control (without application) & - & - \\
\hline 2. 2,4-D & Enlist $^{\mathrm{TM} 3}$ & 975 \\
\hline 3. glyphosate & Glizmax Prime & 1,025 \\
\hline 4. 2,4-D/glyphosate & Enlist Duo ${ }^{\mathrm{TM} 3}$ & $975 / 1,025$ \\
\hline 5. 2,4-D + glyphosate & Enlist $^{\mathrm{TM} 3}+$ Glizmax Prime & $975+1,025$ \\
\hline \multirow[t]{2}{*}{ 6. 2,4-D + glufosinate } & Enlist $^{\mathrm{TM} 3}+$ Finale $^{\infty}$ & $975+460$ \\
\hline & Manufacturer & \\
\hline Enlist $^{\mathrm{TM}}{ }^{\mathrm{c}}$ & Dow AgroSciences Ind. Ltda, São Paulo, Brazil & \\
\hline Enlist Duo ${ }^{\mathrm{TM}} \mathrm{c}$ & Dow AgroSciences Ind. Ltda, São Paulo, Brazil & \\
\hline Glizmax Prime & Dow AgroSciences Ind. Ltda, São Paulo, Brazil & \\
\hline Finale $^{\circ}$ & Bayer CropScience, São Paulo, Brazil & \\
\hline
\end{tabular}

'2,4-D choline salt; glyphosate dimethylamine salt. ${ }^{2}$ Grams of acid equivalent per hectare (g ae ha- ${ }^{-1}$ ), for 2,4-D and glyphosate. Grams of active ingredient per hectare (g ai ha ${ }^{-1}$ ), for glufosinate. ${ }^{3}$ Herbicides with Colex-D'm technology.

Season 2016/17, Mogi-Mirim, São Paulo, Brazil December $1^{\text {st }}, 2016$ to April $29^{\text {th }}, 2017$

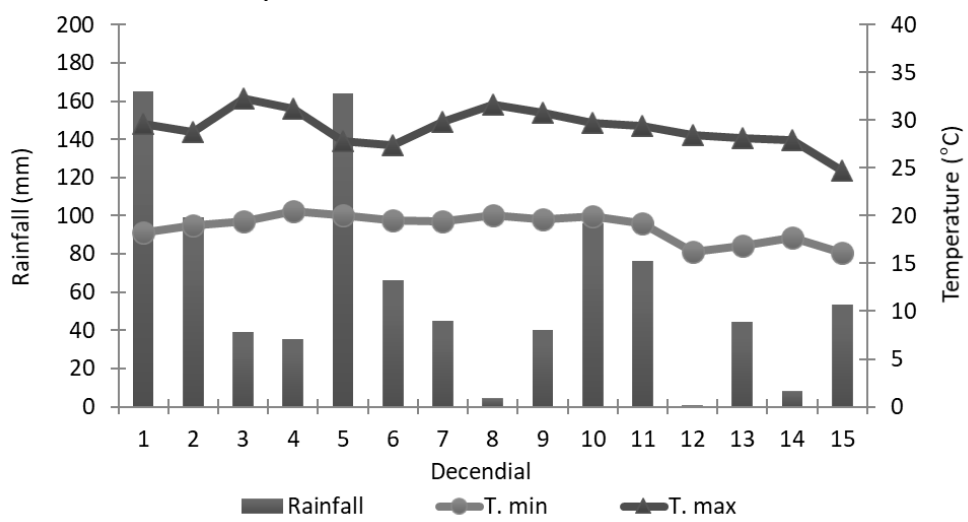

Season 2017/18, Mogi-Mirim, São Paulo, Brazil

December $1^{\text {st }}, 2017$ to April $29^{\text {th }}, 2018$

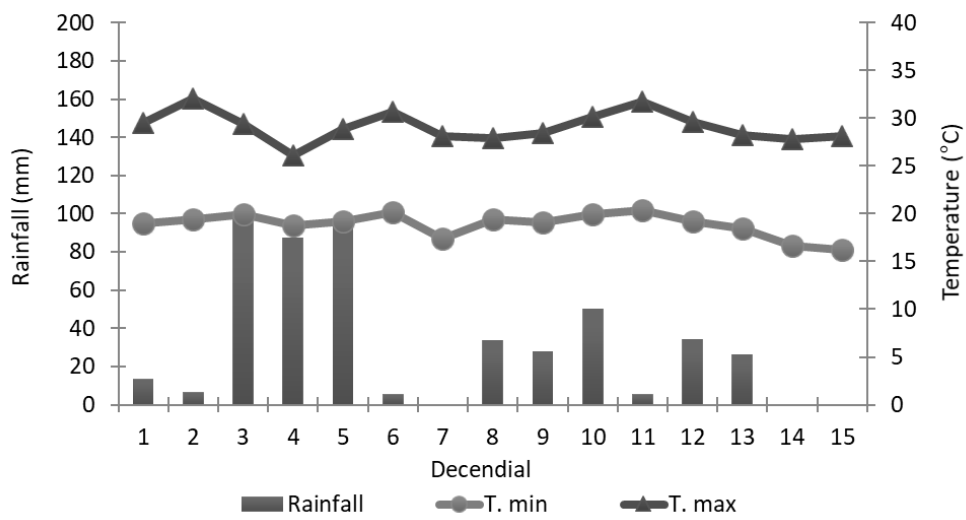

Fig 1. Representation of rainfall, maximum and minimum temperature during the study period of the 2016/17 e 2017/18 seasons

Table 2. Chlorophyll indices (CI) of soybean plants at 1, 2, 3 and 4 WAA of glyphosate $\left(1,440 \mathrm{~g}\right.$ ae ha $\left.{ }^{-1}\right)$. 2016/17 season, Mogi-Mirim, SP, Brazil (experiment 1).

\begin{tabular}{|c|c|c|c|c|c|c|c|c|c|c|c|c|c|c|}
\hline \multirow[t]{2}{*}{ Stage } & \multicolumn{4}{|c|}{ Cl 1 WAA } & \multicolumn{4}{|c|}{$\mathrm{Cl} 2 \mathrm{WAA}$} & \multicolumn{3}{|c|}{$\mathrm{Cl} 3$ WAA } & \multicolumn{3}{|c|}{$\mathrm{Cl} 4 \mathrm{WAA}$} \\
\hline & E3 & & $\mathrm{RR}$ & & E3 & & $\mathrm{RR}$ & & E3 & & $\mathrm{RR}$ & & E3 & $\mathrm{RR}$ \\
\hline & \multicolumn{14}{|c|}{ SPAD index } \\
\hline Control & 40.1 & $a$ & 38.7 & $a$ & 41.0 & $a$ & 40.2 & $a$ & 48.6 & $\mathrm{Aa}$ & 44.6 & $\mathrm{Ba}$ & 46.7 & 44.9 \\
\hline V4 & 36.6 & $b$ & 34.0 & $b$ & 36.6 & $b$ & 35.3 & $\mathrm{~b}$ & 45.8 & $\mathrm{Aa}$ & 41.9 & $\mathrm{Ba}$ & 46.5 & 45.1 \\
\hline V6 & 36.7 & $b$ & 37.1 & $\mathrm{a}$ & 36.8 & $b$ & 37.6 & $a b$ & 45.3 & $A a b$ & 42.3 & $\mathrm{Aa}$ & 47.0 & 46.5 \\
\hline $\mathrm{R} 2$ & 36.5 & $\mathrm{~b}$ & 38.6 & $\mathrm{a}$ & 36.8 & $\mathrm{~b}$ & 40.1 & $\mathrm{a}$ & 41.9 & $\mathrm{Ab}$ & 43.7 & $\mathrm{Aa}$ & 47.1 & 46.5 \\
\hline Mean & 37.3 & & & & 38.1 & & & & 44.3 & & & & 46.3 & \\
\hline CV(\%) & 5.4 & & & & 5.0 & & & & 5.8 & & & & 5.0 & \\
\hline$F_{\text {event (e) }}$ & $0.28^{\mathrm{ns}}$ & & & & $0.58^{\mathrm{ns}}$ & & & & $6.41 *$ & & & & $1.87^{\mathrm{ns}}$ & \\
\hline $\mathrm{F}_{\text {stage (s) }}$ & $5.58 *$ & & & & $8.79 *$ & & & & $3.24 *$ & & & & $0.45^{\mathrm{ns}}$ & \\
\hline $\mathrm{F}_{\mathrm{exs}}$ & $2.06^{\mathrm{ns}}$ & & & & $2.41^{\mathrm{ns}}$ & & & & $2.26 *$ & & & & $0.16^{\text {ns }}$ & \\
\hline
\end{tabular}


Table 3. Chlorophyll A, B and total indices of Enlist E3 soybean plants at 1, 2, 3 and 4 WAA of herbicides application. 2017/18 season, Mogi-Mirim, SP, Brazil (experiment 2)

\begin{tabular}{|c|c|c|c|c|c|c|c|c|}
\hline \multirow{3}{*}{ Treatments $^{1}$} & \multicolumn{8}{|c|}{ Chlorophyll index } \\
\hline & \multicolumn{4}{|l|}{1 WAA } & \multicolumn{4}{|c|}{2 WAA } \\
\hline & $\mathrm{A}$ & $\mathrm{B}$ & Total & & A & & $\mathrm{B}$ & Total \\
\hline & FC index & & & & & & & \\
\hline 1. control & 30.2 & 7.5 & 37.7 & & 22.4 & & 9.8 & 32.2 \\
\hline 2. 2,4-D & 27.8 & 6.7 & 34.6 & & 21.0 & & 11.0 & 32.0 \\
\hline 3. glyphosate & 28.8 & 6.5 & 35.3 & & 23.1 & & 7.4 & 30.5 \\
\hline 4. 2,4-D/glyphosate & 29.8 & 6.5 & 36.5 & & 23.7 & & 7.7 & 31.3 \\
\hline 5. 2,4-D + glyphosate & 28.0 & 6.7 & 34.7 & & 20.9 & & 8.6 & 29.5 \\
\hline 6. 2,4-D + glufosinate & 28.5 & 7.4 & 35.9 & & 24.4 & & 8.2 & 32.6 \\
\hline Mean & 28.9 & 6.9 & 35.8 & & 22.6 & & 8.8 & 31.4 \\
\hline CV (\%) & 7.8 & 20.1 & 8.8 & & 12.7 & & 19.9 & 11.5 \\
\hline $\mathrm{F}$ & $0.73^{\mathrm{ns}}$ & $0.41^{\mathrm{ns}}$ & $0.56^{\mathrm{ns}}$ & & $0.99^{\mathrm{ns}}$ & & $2.46^{\mathrm{ns}}$ & $0.43^{\mathrm{ns}}$ \\
\hline \multirow[t]{3}{*}{ Treatments $^{1}$} & 3 WAA & & & & 4 WAA & & & \\
\hline & $\mathrm{A}$ & $\mathrm{B}$ & Total & & $\mathrm{A}$ & & $\mathrm{B}$ & Total \\
\hline & FC index & & & & & & & \\
\hline 1. control & 26.5 & 8.5 & 35.0 & $a b$ & 26.8 & $a b$ & 8.8 & 35.6 \\
\hline 2. 2,4-D & 24.3 & 6.8 & 31.1 & $b$ & 24.4 & $\mathrm{~b}$ & 9.3 & 33.6 \\
\hline 3. glyphosate & 27.5 & 9.2 & 36.7 & $a b$ & 27.0 & $a b$ & 7.2 & 34.1 \\
\hline 4. 2,4-D/glyphosate & 24.8 & 7.6 & 32.4 & $a b$ & 25.4 & $a b$ & 7.3 & 32.8 \\
\hline 5. 2,4-D + glyphosate & 25.9 & 9.4 & 35.3 & $a b$ & 25.4 & $a b$ & 7.8 & 33.3 \\
\hline 6. 2,4-D + glufosinate & 28.8 & 11.3 & 40.0 & $a$ & 27.8 & $\mathrm{a}$ & 8.0 & 35.7 \\
\hline Mean & 26.3 & 8.8 & 35.1 & & 26.2 & & 8.1 & 34.2 \\
\hline CV (\%) & 7.6 & 27.7 & 10.0 & & 5.8 & & 12.5 & 6.1 \\
\hline $\mathrm{F}$ & $2.76^{\mathrm{ns}}$ & $1.64^{\mathrm{ns}}$ & $3.27 *$ & & $2.95 *$ & & $2.79^{\mathrm{ns}}$ & $1.53^{\mathrm{ns}}$ \\
\hline
\end{tabular}
.

Table 4. Variables related to the agronomic performance of soybean plants under application of glyphosate $\left(1,440 \mathrm{~g}\right.$ ae ha $\left.{ }^{-1}\right)$. Mogi-Mirim, SP, Brazil (experiment 1)

\begin{tabular}{|c|c|c|c|c|c|c|c|c|}
\hline \multicolumn{9}{|c|}{ Season $2016 / 17$} \\
\hline \multirow[t]{2}{*}{ Stage } & \multicolumn{2}{|l|}{ Heigth } & \multicolumn{2}{|c|}{ Pods plant $^{-1}$} & \multicolumn{2}{|l|}{ Yield } & \multicolumn{2}{|c|}{ Mass of 1,000 grains } \\
\hline & E3 & $\mathrm{RR}$ & E3 & $\mathrm{RR}$ & E3 & $\mathrm{RR}$ & E3 & $\mathrm{RR}$ \\
\hline & $\mathrm{cm}$ & & & & $\mathrm{kg} \mathrm{ha}^{-1}$ & & g & \\
\hline control & 84.3 & 87.8 & 48.0 & 45.5 & 3,317 & 3,540 & 160.1 & 157.0 \\
\hline V4 & 85.1 & 86.6 & 48.7 & 46.4 & 3,334 & 3,472 & 164.7 & 158.7 \\
\hline V6 & 83.9 & 86.2 & 50.5 & 46.5 & 3,301 & 3,581 & 164.0 & 158.4 \\
\hline R2 & 81.9 & 86.7 & 44.2 & 44.8 & 3,277 & 3,223 & 165.5 & 157.7 \\
\hline Mean & 85.3 & & 46.8 & & 3,381 & & 160.8 & \\
\hline CV (\%) & 2.6 & & 12.1 & & 12.0 & & 4.9 & \\
\hline $\mathrm{F}_{\text {event (e) }}$ & $15.07^{\mathrm{ns}}$ & & $1.05^{\mathrm{ns}}$ & & $1.04^{\mathrm{ns}}$ & & $4.04^{\mathrm{ns}}$ & \\
\hline $\mathrm{F}_{\text {stage (s) }}$ & $1.09^{\mathrm{ns}}$ & & $0.71^{\mathrm{ns}}$ & & $0.38^{\mathrm{ns}}$ & & $0.28^{\mathrm{ns}}$ & \\
\hline $\mathrm{F}_{\text {exs }}$ & $0.84^{\mathrm{ns}}$ & & $0.24^{\mathrm{ns}}$ & & $0.26^{\mathrm{ns}}$ & & $0.12^{\text {ns }}$ & \\
\hline \multicolumn{9}{|c|}{ Season $2017 / 18$} \\
\hline & Heigth & & Pods pl & & Yield & & Mass o & \\
\hline \multirow[t]{2}{*}{ Stage } & E3 & $\mathrm{RR}$ & E3 & RR & E3 & RR & E3 & RR \\
\hline & $\mathrm{cm}$ & & & & $\mathrm{kg} \mathrm{ha}^{-1}$ & & $\mathrm{~g}$ & \\
\hline control & 65.4 & 62.6 & 39.9 & 38.7 & 2,859 & 2,871 & 217.5 & 209.1 \\
\hline V4 & 63.6 & 62.0 & 39.8 & 38.7 & 2,822 & 2,705 & 214.0 & 227.2 \\
\hline V6 & 65.4 & 61.2 & 43.0 & 37.9 & 2,967 & 2,671 & 216.5 & 213.9 \\
\hline R2 & 62.0 & 60.4 & 38.8 & 38.6 & 2,855 & 2,667 & 220.8 & 216.9 \\
\hline Mean & 62.9 & & 39.4 & & 2,798 & & 216.6 & \\
\hline CV (\%) & 2.3 & & 7.6 & & 9.8 & & 5.9 & \\
\hline $\mathrm{F}_{\text {event (e) }}$ & $29.53^{\mathrm{ns}}$ & & $3.19^{\mathrm{ns}}$ & & $2.02^{\mathrm{ns}}$ & & $0.01^{\mathrm{ns}}$ & \\
\hline $\mathrm{F}_{\text {stage (s) }}$ & $3.41^{\mathrm{ns}}$ & & $0.50^{\text {ns }}$ & & $0.26^{\mathrm{ns}}$ & & $0.75^{\mathrm{ns}}$ & \\
\hline $\mathrm{F}_{\mathrm{exs}}$ & $1.02^{\mathrm{ns}}$ & & $1.09^{\mathrm{ns}}$ & & $0.35^{\mathrm{ns}}$ & & $0.92^{\mathrm{ns}}$ & \\
\hline
\end{tabular}

Table 5. Variables related to the agronomic performance of Enlist E3 soybean plants under application of herbicides. Mogi-Mirim, SP, Brazil (experiment 2)

\begin{tabular}{|c|c|c|c|c|c|c|c|c|c|}
\hline \multirow[b]{2}{*}{ Treatments $^{1}$} & \multicolumn{4}{|c|}{ 2016/17 season } & \multicolumn{5}{|c|}{$2017 / 18$ season } \\
\hline & $\mathrm{H}$ & Pods plant $^{-1}$ & MG & Yield & $\mathrm{H}$ & Pods plant $^{-1}$ & & MG & Yield \\
\hline & $\mathrm{cm}$ & & $\mathrm{g}$ & $\mathrm{kg} \mathrm{ha}^{-1}$ & $\mathrm{~cm}$ & & & g & $\mathrm{kg} \mathrm{ha}^{-1}$ \\
\hline 1. control & 81.7 & 42.5 & 166.1 & 3,008 & 65.0 & 44.6 & a & 204.3 & 2,432 \\
\hline 2. 2,4-D & 84.0 & 44.2 & 165.4 & 2,966 & 68.4 & 42.9 & $a b$ & 202.4 & 2,486 \\
\hline 3. glyphosate & 81.6 & 40.3 & 159.7 & 2,969 & 65.8 & 39.8 & $a b$ & 207.7 & 2,501 \\
\hline 4. 2,4-D/glyphosate & 82.9 & 40.0 & 172.9 & 3,174 & 64.8 & 41.9 & $a b$ & 210.0 & 2,375 \\
\hline 5. 2,4-D + glyphosate & 82.9 & 42.4 & 163.5 & 3,238 & 66.9 & 42.1 & $a b$ & 208.3 & 2,527 \\
\hline 6. 2,4-D + glufosinate & 84.0 & 41.9 & 165.1 & 3,133 & 67.8 & 39.1 & $\mathrm{~b}$ & 211.5 & 2,542 \\
\hline Mean & 82.8 & 41.9 & 165.4 & 3,081 & 66.4 & 41.8 & & 207.4 & 2,477 \\
\hline CV (\%) & 3.7 & 13.1 & 5.2 & 10.7 & 2.9 & 5.1 & & 3.2 & 9.1 \\
\hline $\mathrm{F}$ & $0.45^{\mathrm{ns}}$ & $0.32^{\mathrm{ns}}$ & $1.01^{\mathrm{ns}}$ & $0.50^{\mathrm{ns}}$ & $2.37^{\mathrm{ns}}$ & $3.73 *$ & & $1.03^{\mathrm{ns}}$ & $0.31^{\mathrm{ns}}$ \\
\hline
\end{tabular}

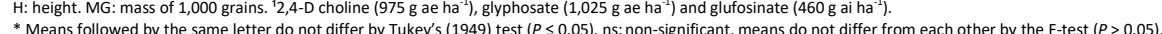


This result corroborates the findings for application of glyphosate in Enlist E3 soybean in the present study. Importantly, glyphosate can be applied in RR soybean until R1 (Rodrigues and Almeida, 2018) while glyphosate application can be performed up to the R2 in Enlist E3 soybean (Chahal et al., 2015). However, as previously noted for application in the R2 of RR soybean, there were no yield reductions. There were only a few reductions in chlorophyll indices in comparison to control for both events. However, there were subtle differences, which were found only in the first season.

The Enlist E3 soybean plants had a maximum of 3\% injury after application of 2,4-D choline, glyphosate and glufosinate at V4, without differences for the control (without application) for experiment 2. Similarly, Schryver et al. (2017) found crop injury in Enlist E3 soybean of almost 2\%, after application of the of 2,4-D choline/glyphosate $\left(838.5 / 881.5 \mathrm{~g}\right.$ a.e. $\left.\mathrm{ha}^{-1}\right)$, alone or in combination with preemergence herbicides. Robinson et al. (2015) found a maximum of $3 \%$ crop injury in DAS68416 (aad-12 transformed) soybean after application of 2,4-D dimethylamine in different chemical management programs. Miller and Norsworthy (2016) did not find yield reductions in Enlist E3 soybean after application of 2,4-D choline, glyphosate and glufosinate in different chemical management programs. Frene et al. (2018) found crop injury up to 23\% (1 WAA) in Enlist E3 soybean, for application of glyphosate $\left(1,440-2,280 \mathrm{~g}^{2}\right.$ ae ha $\left.{ }^{-1}\right)+2,4$-D choline $(1,440-$ $2,280 \mathrm{~g}$ ae $\mathrm{ha}^{-1}$ ) at $\mathrm{V} 3$, whereas symptoms did not exceed $5 \%$ at 3 WAA with no yield reductions. Kalsing et al. (2018) verified the tolerance of soybean DAS-44406-6 and DAS44406-6 6 DAS-81419-2 for the application of 2,4-D choline/glyphosate $\left(1,950 / 2,050 \mathrm{~g}_{\text {ae }} \mathrm{h}^{-1}\right)$ to the V3, V6 and R2. Crop injury of up to $13 \%$ was observed at 7 DAA for V6 without any reductions in yield.

The application of glufosinate (450 $\mathrm{g}$ ai $\mathrm{ha}^{-1}$ ) alone or in mixture with $2,4-\mathrm{D}$ amine $\left(1,120 \mathrm{~g}^{\mathrm{ea} \mathrm{h}} \mathrm{ha}^{-1}\right)$, at postemergence, provided a maximum of $3 \%$ crop injury in soybean tolerant to 2,4-D choline and glufosinate (aad-12 and pat transformed) (Craigmyle et al., 2013). In glufosinatetolerant soybean (pat transformed), no crop injury and yield reductions were found for post-emergence application of glufosinate in different chemical management programs (Barnes et al., 2017), as confirmed in the present study for Enlist E3 soybean.

Although there were some differences in chlorophyll indices, none of the applied herbicides reduced the chlorophyll indices of Enlist E3 soybean plants compared to the control (without application). These results are in accordance with the findings for crop injury. There are no reported effects of 2,4-D choline, glyphosate and glufosinate on the chlorophyll indices of E3 soybean, which confirms the results of the present study. The tolerance of the Enlist E3 soybean to 2,4D choline, glyphosate and glufosinate for application at postemergence is of noteworthy. In the present study, among the agronomic performance variables, there were differences between treatments only for number of pods per plant in the 2017/18 season. Application of 2,4-D choline + glufosinate reduced pods compared to the control.

In addition, the results found in the present study and others cited the selectivity of 2,4-D choline, glyphosate and glufosinate in Enlist E3 soybean. Other studies also highlighted the effectiveness of these herbicides in weed control, as reported by Meyer et al. (2015). Thus, there is a possibility of using other herbicides in addition to glyphosate on Enlist E3 soybean. This may be an alternative for control and prevention of the selection of glyphosate resistant weeds, since the association and rotation of herbicides with different mechanisms of action are important in this sense.

\section{Materials and methods}

\section{Local description}

The present study consisted of two experiments ( 1 and 2) carried out in the 2016/17 and 2017/18 seasons at MogiMirim, São Paulo state (SP), Brazil $\left(22^{\circ} 26^{\prime} 45.7^{\prime \prime S}\right.$ $\left.47^{\circ} 04^{\prime} 21.8^{\prime \prime} \mathrm{W}\right)$. The climate of the region is characterized as Cwa by the Köppen climate classification, which is humid subtropical with drought in the winter. The distribution of rainfall and temperature along the conduction period is shown below (Figure 1). For the 2016/17 season, sowing occurred in December $26^{\text {th }}, 2016$ with harvest on April $17^{\text {th }}$, 2017. For the $2017 / 18$ season, sowing was occurred between December $19^{\text {th }} 2017$ with harvest on April $10^{\text {th }}$ 2018. The plots were maintained weed free by handweeding. The physical and chemical soil analysis of the experimental area presented $\mathrm{pH}\left(\mathrm{CaCl}_{2}\right): 5.5, \mathrm{CEC}: 57.6$ $\mathrm{mmol}_{\mathrm{c}} \mathrm{dm}^{-3}$, V: $46 \%$, clay: $47.6 \%$, silt: $3.1 \%$ and sand: $49.3 \%$.

\section{Plant materials and experimental design}

The experiment 1 consisted of application of glyphosate [dimethylamine salt] (Glizmax Prime, Dow AgroSciences) at rate of $1,440 \mathrm{~g}$ acid equivalent (ae) ha $^{-1}$. The treatments were arranged in $2 \times 4$ factorial (event $x$ growth stage). For the event factor, DAS-44406-6 (Enlist E3 ${ }^{\text {TM }}$ soybean) and GTS 40-3-2 (Roundup Ready ${ }^{\mathrm{TM}}$ - RR soybean) were used. For growth stage, control (without application), V4, V6 and R2 were implemented. Experiment 2 consisted of herbicide application at post-emergence (V4) of Enlist E3 soybean plants (Table 1).

A randomized block design with four replications was adopted. The experimental units consisted of $5 \mathrm{~m}$ long plots and four soybean rows, spaced at $0.5 \mathrm{~m}$. The cultivars Enlist E3 (Dow AgroSciences) and BMX Turbo RR/STS (GDM Genética do Brasil) were used (for experiment 2, only Enlist E3), both with indeterminate habit growth and relative maturity group 5.7 and 5.8, respectively. The herbicides were applied with a $\mathrm{CO}_{2}$ pressurized backpack sprayer, with a bar fitted with four spray nozzles (Al 110.015) at 40 psi pressure, working at a height of $50 \mathrm{~cm}$ from the target, and at $1 \mathrm{~m} \mathrm{~s}^{-1}$, reaching an applied band width of $50 \mathrm{~cm}$ by spray nozzle and spray volume of $150 \mathrm{~L} \mathrm{ha}{ }^{-1}$.

\section{Assessment and data collection}

Crop injury was determined through visual evaluations; percentage marks were assigned to each experimental unit (0 for no injury, up to $100 \%$ for plant death) (Velini et al., 1995). For experiment 1, crop injury evaluation was performed at 1, 2, 3 and 4 weeks after application (WAA) of last growth stage (R2). At experiment 2, it was performed at $1,2,3$ and 4 WAA.

At the same assessment dates, chlorophyll index was evaluated in 10 randomly selected plants. For the 2016/17 season, chlorophyll index was measured by a portable meter (SPAD-502, Konica Minolta). This instrument quantitatively evaluates leaf green intensity by measuring light transmissions. Based on these values, the equipment calculates the Soil Plant Analysis Development (SPAD) index, which is usually highly correlated with leaf chlorophyll content (Uddling et al., 2007). For the $2017 / 18$ season, the 
indices of chlorophyll A, B and total were measured with an electronic chlorophyll meter (clorofiLOG - CFL1030, Falker Automação Agrícola). This equipment determines the Falker chlorophyll (FC) indices (Barbieri Júnior et al., 2012). The chlorophyll index, for all experiments, was always evaluated in the central leaf of a fully developed trefoil of the upper third of the plant.

Variables relative to agronomic performance (plant height, number of pods per plant, yield, and mass of 1,000 grains) were also evaluated. Height and number of pods were evaluated at full maturation (R8), by manually counting the number of pods present on 10 plants randomly chosen in each plot. The plants of the two central rows were harvested manually, and the first and last meter of the plot was discarded, yielding a total harvested area of $3 \mathrm{~m}^{2}$. Pods were threshed, cleaned, and packed in paper bags for use in further assessments. The weight of the grains produced in each plot was measured and their moisture was adjusted to $13 \%$. These data were used to calculate yield in $\mathrm{kg} \mathrm{ha}^{-1}$; 1,000 -grain weight was determined by calculating the mean weight of the two sub-samples of 100 grains per plot, values were multiplied by 10 and moisture was adjusted to $13 \%$.

\section{Statistical analysis}

Data were analyzed according to Pimentel-Gomes and Garcia (2002). For this we used the software Sisvar 5.6 (Ferreira, 2011). Analysis of variance were performed $(P \leq$ $0.05)$. In experiment 1 , for the stage factor, the means were compared by LSD (least significant difference) test $(P \leq 0.05)$, while the F-test $(P \leq 0.05)$ was conclusive for comparing the means of the event factor. For experiment 2, means were compared by Tukey's (1949) test $(P \leq 0.05)$.

\section{Conclusions}

In general, no differences were found between chlorophyll indices of Enlist E3 and Roundup Ready soybean after application of glyphosate $\left(1,440 \mathrm{~g}\right.$ ae ha $\left.{ }^{-1}\right)$ at postemergence for different growth stages. There were no effects of glyphosate $\left(1,440 \mathrm{~g}\right.$ ae ha $\left.{ }^{-1}\right)$ at post-emergence at different growth stages on agronomic performance of Enlist E3 and Roundup Ready soybean. Thus, these studies verify the equivalent selectivity of glyphosate for Enlist E3 and Roundup Ready soybean, regardless of the growth stage.

The 2,4-D choline, alone or in mixture with glyphosate (premix formulation or tank mixture) or glufosinate, did not reduce the chlorophyll indices and yield of Enlist E3 soybean for post-emergence (V4) application. Thus, Enlist E3 soybean was found to be tolerant to a single and mixture application of 2,4-D choline (975 $\mathrm{g}$ ae ha $\left.{ }^{-1}\right)$ and glyphosate $(1,025 \mathrm{~g}$ ae $\mathrm{ha}^{-1}$ ) and glufosinate (460 $\mathrm{g}$ ai ha ${ }^{-1}$ ).

\section{References}

Albrecht AJP, Albrecht LP, Barroso AAM, Cesco VJS, Krenchinski FH, Silva AFM, Victoria Filho R (2018) Glyphosate tolerant soybean response to different management systems. J Agric Sci. 10(1):204-216.

Albrecht LP, Barbosa AP, Silva AFM, Mendes MA, MaraschiSilva LM, Albrecht AJP (2011) Performance of Roundup Ready soybean under glyphosate application at different stages. Planta Daninha. 29(3):585-590.
Barbieri Júnior E, Rossiello ROP, Silva RVMM, Ribeiro RC, Morenz MJF (2012) A new chlorophyll meter to estimate chlorophyll contents in leaves of Tifton 85 bermudagrass. Cienc Rural. 42(12):2242-2245.

Barnes ER, Knezevic SZ, Sikkema PH, Lindquist JL, Jhala AJ (2017) Control of glyphosate-resistant common ragweed (Ambrosia artemisiifolia L.) in glufosinate-resistant soybean Glycine max (L.) Merr. Front Plant Sci. 8:1445.

Bohm GMB, Rombaldi CV, Genovese MI, Castilhos D, Alves BJR, Rumjanek NG (2014) Glyphosate effects on yield, nitrogen fixation, and seed quality in glyphosate-resistant soybean. Crop Sci. 54(4):1737-1743.

Chahal PS, Aulakh JS, Rosenbaum K, Jhala AJ (2015) Growth stage affects dose response of selected glyphosateresistant weeds to premix of 2,4-D choline and glyphosate (Enlist Duo ${ }^{\mathrm{TM}}$ Herbicide). J Agric Sci. 7(11):1-10.

Craigmyle BD, Ellis JM, Bradley KW (2013) Influence of herbicide programs on weed management in soybean with resistance to glufosinate and 2,4-D. Weed Technol. 27(1):78-84.

Ferreira DF (2011) Sisvar: a computer statistical analysis system. Cienc Agrotecnol. 35(6):1039-1042.

Frene RL, Simpson DM, Buchanan MB, Vega ET, Ravotti ME, Valverde PP (2018) Enlist E3 ${ }^{\mathrm{TM}}$ soybean sensitivity and Enlist $^{\mathrm{TM}}$ herbicide-based program control of Sumatran fleabane (Conyza sumatrensis). Weed Technol. 32(4):1-8.

Green JM (2009) Evolution of glyphosate-resistant crop technology. Weed Sci. 57(1):108-117.

Jhala AJ, Sandell LD, Sarangi D, Kruger GR, Knezevic SZ (2017) Control of glyphosate-resistant common waterhemp (Amaranthus rudis) in glufosinate-resistant soybean. Weed Technol. 31(1):32-45.

Kalsing A, Lucio FR, Rossi CVS, Rampazzo PE, Gonçalves FP, Valeriano R (2018) Tolerance of DAS-444Ø6-6 and DAS444Ø6-6 x DAS-81419-2 soybeans to 2,4-D and glyphosate in the Cerrado region of Brazil. Planta Daninha 36:e018174410.

Lepping MD, Herman RA, Potts BL (2013) Compositional equivalence of DAS-444Ø6-6 (AAD-12 + 2mEPSPS + PAT) herbicide-tolerant soybean and nontransgenic soybean. J Agric Food Chem. 61(46):11180-11190.

Meyer CJ, Norsworthy JK, Young BG, Steckel LE, Bradley KW, Johnson WG, Loux MM, Davis VM, Kruger GR, Bararapour MT, Ikley JT, Spaunhorst DJ, Butts TR (2015) Herbicide program approaches for managing glyphosate-resistant palmer amaranth (Amaranthus palmeri) and waterhemp (Amaranthus tuberculatus and Amaranthus rudis) in future soybean-trait technologies. Weed Technol. 29(4):716-729.

Miller MR, Norsworthy JK (2016) Evaluation of herbicide programs for use in a 2,4-D-resistant soybean technology for control of glyphosate-resistant palmer amaranth (Amaranthus palmeri). Weed Technol. 30(2):366-376.

Oliveira Júnior RS (2011) Mecanismos de ação dos herbicidas. In: Oliveira Júnior RS, Constantin J, Inoue $\mathrm{MH}$ (eds) Biologia e manejo de plantas daninhas. Omnipax, Curitiba.

Padgette SR, Kolacz KH, Delannay X, Re DB, Lavallee BJ, Tinius CN, Rhodes WK, Otero YI, Barry GF, Eichholtz DA, Peschke VM, Nida DL, Taylor NB, Kishore GM (1995) Development, identification, and characterization of a glyphosate-tolerant soybean line. Crop Sci. 35(5):14511461.

Peterson MA, McMaster SA, Riechers DE, Skelton J, Stahlman PW (2016) 2,4-D past, present, and future: a review. Weed Technol. 30(2):303-345. 
Pimentel-Gomes F, Garcia CH (2002) Estatística aplicada a experimentos agronômicos e florestais: exposição com exemplos e orientações para uso de aplicativos. Fealq, Piracicaba.

Reddy KN, Rimando AM, Duke SO (2004) Aminomethylphosphonic acid, a metabolite of glyphosate, causes injury in glyphosate-treated, glyphosate-resistant soybean. J Agric Food Chem. 52(16):5139-5143.

Robinson AP, Simpson DM, Johnson WG (2015) Response of aryloxyalkanoate dioxygenase-12 transformed soybean yield components to postemergence 2,4-D. Weed Sci. 63(1):242-247.

Rodrigues BN, Almeida FS (2018) Guia de herbicidas, 7th ed. Londrina, Ed. Authors.

Schryver MG, Soltani N, Hooker DC, Robinson DE, Tranel PJ, Sikkema PH (2017) Control of glyphosate-resistant common waterhemp (Amaranthus rudis) in three new herbicide-resistant soybean varieties in Ontario. Weed Technol. 31(6):828-837.
Silva AFM, Albrecht AJP, Albrecht LP, Victoria Filho $R$, Giovanelli BF (2016) Application of post-emergence ALS inhibitor herbicides associated or not to glyphosate in RR/STS soybean. Planta Daninha. 34(4):765-775.

Tukey JW (1949) Comparing individual means in the analysis of variance. Biometrics. 5(2):99-114.

Uddling J, Gelang-Alfredsson J, Piikki K, Pleijel H (2007) Evaluating the relationship between leaf chlorophyll concentration and SPAD-502 chlorophyll meter readings. Photosynth Res. 91(1):37-46.

Velini ED, Osipe R, Gazziero DLP (1995) Procedimentos para instalação, avaliação e análise de experimentos com herbicidas. SBCPD, Londrina.

Wallace RD, Sosnoskie LM, Culpepper AS, York AC, Edmisten KL, Patterson MG, Jones MA, Crooks HL, Cloud GL, Pierson J (2011) Tolerance of GlyTol and GlyTol + LibertyLink cotton to glyphosate and glufosinate in the southeastern US. J Cotton Sci. 15:80-88.

Zobiole LHS, Kremer RJ, Oliveira Júnior RS, Constantin J (2010) Glyphosate affects photosynthesis in first and second generation of glyphosate-resistant soybeans. Plant Soil. 336(1-2):251-265. 